\title{
Comparison of Immigrants and Turkish Patients Hospitalized in the ICU with the Diagnosis of Gastrointestinal Cancer in Terms of Malnutrition and Its Effects on Mortality
}

\author{
Yoğun Bakım Ünitesinde Gastrointestinal Kanser ile Yatan Hastalarda \\ Malnutrisyon ve Mortalite Üzerindeki Etkileri Açısından Göçmen ve Türk \\ Hastaların Karşılaştırılması
}

\author{
Begum Seyda Avci ${ }^{1} \oplus$, Adnan Kuvvetli ${ }^{2}$, Alper Parlakgumus ${ }^{3 \oplus}$ \\ ${ }^{1}$ Health Science University, Adana City Research and Training Hospital, Department of Internal Medicine, Adana, Turkey \\ ${ }^{2}$ Health Science University, Adana City Research and Training Hospital, Department of General Surgery, Adana, Turkey. \\ ${ }^{3}$ Health Science University, Adana City Research and Training Hospital, Department of Surgical Oncology, Adana, Turkey
}

Received: 11.11.2020 / Accepted: 01.12.2020 / Published Online: 29.12.2020

Cite as: Avci BS, Kuvvetli A, Parlakgumus A. Comparison of ımmigrants and Turkish patients hospitalized in the Icu with the diagnosis of gastrointestinal cancer in terms of malnutrition and its effects on mortality. Med J Bakirkoy 2020;16(4):406-11.

\section{ABSTRACT}

Objective: The aim of this study was to compare the effects of malnutrition on mortality in immigrants and Turkish patients hospitalized in our ICU with the indication of gastrointestinal cancer.

Method: This study was performed as a prospective observational study. One-hundered and three (41.3\%) patients were Turkish and 146 (58.7\%) were immigrants (all Syrian). Age, body mass index (BMI), duration of hospitalization, albumin value, and 30-day and 6-month mortality rates were evaluated. Also, the following assessment tools were calculated: Subjective Global Assessment (SGA), Nutrition risk screening-2002 (NRS), Charlson Comorbidity Index (CCI) Acute Physiology and Chronic Health Evaluation (APACHE) II and III.

Results:In total, 150 (60.2\%) patients had moderate (SGA B), while 71 (28.5\%) patients had severe malnutrition (SGA C). The frequency of SGA $C$ in the immigrants was significantly higher than Turkish ciitzens $(p=0.004)$. The overall mortality rate in our study was $36.9 \%$. No significant difference was found between Turkish citizens and immigrants in terms of overall mortality ( $p=0.592)$. Albumin value, APACHE II, APACHE III, CCl and NRS scores were significantly higher in those that died within 30 days. The APACHE 3 score was the most successful tool in predicting 30-day mortality according to ROC analyses.

Conclusion: This study revealed that malnutrition is a significant problem for both immigrants and Turkish citizens hospitalized in the ICU. Although there are tools specific for malnutrition assessment, APACHE III score was found to have the highest likelihood to predict mortality.

Keywords: Malnutrition, immigrants, subjective global assessment, mortality

Öz

Amaç: Bu çalışmanın amacı, mide bağırsak kanseri nedeniyle yoğun bakım ünitemize yatırılan göçmen ve Türk hastalarda malnütrisyonun mortalite üzerindeki etkilerini karşılaştırmaktır.

Yöntem: Bu çalışma ileriye dönük gözlemsel çalışma olarak yapıldı. Hastaları 103’ü Türk (\% 41,3), 146'sı (\% 58,7) göçmendi (Tümü Suriyeli). Yaş, vücut kitle indeksi (VKi), hastanede kalış süresi, albümin değeri ve 30 günlük ve 6 aylık mortalite değerlendirildi. Ayrıca, aşağıdaki değerlendirme skorlamaları hesaplandı: Subjektif Global Değerlendirme (SGA), Nütrisyon Risk Değerlendirmesi-2002 (NRS), Charlson Komorbidite Indeksi (CCI) Akut Fizyoloji ve Kronik Sağlık Değerlendirmesi (APACHE) II ve III.

Bulgular: Toplamda 150 (\% 60,2) hastada orta düzeyde yetersiz beslenme (SGA B) varken 71 (\% 28,5) hastada şiddetli beslenme bozukluğu (SGA C) vardı. Göçmenlerde SGA C sıklığı Türk vatandaşlarına göre anlamlı olarak daha yüksekti $(p=0,004)$. Çalışmamızdaki genel ölüm oranı\% 36,9'du. Genel ölüm oranları açısından Türk vatandaşları ve göçmenler arasında anlamlı bir fark bulunmadı ( $p=$ 0.592). 30 gün içinde ölenlerde albümin değeri, APACHE II, APACHE III, CCI ve NRS skorları anlamlı olarak yüksekti. APACHE 3 skoru, ROC analizlerine göre 30 günlük mortaliteyi tahmin etmede en başarılı olanıydı.

Sonuç: Bu çalıșma yetersiz beslenmenin hem göçmenler hem de yoğun bakım ünitesinde yatan Türk vatandaşları için önemli bir sorun olduğunu ortaya koymuştur. Yetersiz beslenme değerlendirmesi için özel araçlar olmasına rağmen, APACHE III skorunun mortaliteyi tahmin etme olasılığının en yüksek olduğu bulunmuştur.

Anahtar kelimeler: Malnütrisyon, göçmenler, subjektif global değerlendirme, mortalite

Corresponding Author:

aparlakgumus@yahoo.com
B.S. Avcl 0000-0001-6149-9341

A. Kuvvetli 0000-0002-0725-6629

A. Parlakgumus : 0000-0002-7922-2794

(C) Telif hakkı Sağlık Bilimleri Üniversitesi Bakırköy Dr. Sadi Konuk Eğitim ve Araştırma Hastanesi'ne aittir. Logos Tıp Yayıncılık tarafından yayınlanmaktadır. Bu dergide yayınlanan bütün makaleler Creative Commons Atff-GayriTicari 4.0 Uluslararası Lisansı ile lisanslanmıştır.

(c) Copyright Health Sciences University Bakırköy Sadi Konuk Training and Research Hospital. This journal published by Logos Medical Publishing.

Licenced by Creative Commons Attribution-NonCommercial 4.0 International (CC BY) 


\section{INTRODUCTION}

In recent years, the war in Syria has led to the spread of large immigrant groups to many countries including Turkey. When people migrate, the first requirements are the most basic human needs, such as nutrition and health care. Immigrants have often faced several problems, the most important of them being nutritional deficiency in areas where they migrate to take refuge $(1,2)$.

Although malnutrition has been shown to disproportionately affect children, it can also be seen in adults, especially in the elderly, and may cause significant health problems ${ }^{(3,4)}$. In general, malnutrition in adults is associated with a decrease in general functional status and reduced bone mass, immune dysfunction, delayed postoperative recovery, higher hospitalization and readmission rates, and increased mortality ${ }^{(5,6)}$.

In disadvantaged groups such as refugees or immigrants, the impact of malnutrition on overall health is more pronounced ${ }^{(7)}$. Malnutrition in immigrants and refugees should be viewed not only as a health issue, but also as a serious lack of access to basic human rights. Although there are many studies on the effect and frequency of malnutrition in child immigrants, very few studies have assessed its impact on the adult age group ${ }^{(8-10)}$.

The aim of the present study is to compare hospitalized adult immigrants and Turkish patients with gastrointestinal cancer in intensive care units (ICU) in terms of malnutrition and its effects on mortality.

\section{MATERIAL and METHODS}

\section{Patients}

This is a prospective study including 249 patients, who were hospitalized at our intensive care unit (ICU) between October 2017 - December 2018. All subjects had a diagnosis of colorectal or non-colorectal gastrointestinal cancer and were consulted to the Department of Nutrition and Dietetics at xxxxxxx hospital/medical faculty with suspect malnutrition. All subjects were followed for six months (the first follow up visit was scheduled one month after discharge). Hundred and three (41.3\%) patients were Turkish citizens and 146 (58.7\%) were immigrants. All the immigrants were Syrians. Inclusion criteria were as follows: having a gastrointestinal cancer (colorectal or non-colorectal), being con- sulted to our nutrition team due to a suspicion for malnutrition, accepting to participate in the study by providing written informed consent, and not being an alcohol or drug abuser. Exclusion criteria were as follows: being younger than 18 years of age, having any diagnosis other than colorectal or non-colorectal gastrointestinal cancer and refusing to participate in the study or withdrawing at any time.

\section{Ethics}

\section{Measurements}

Age, body mass index (BMI), duration of hospitalization, albumin value and mortality (30-day and 6-month) were evaluated in all patients. Mortality was assessed as intra-hospital and overall mortality at both 30 days and 6 months. In addition, the screening tools explained below were used to assess malnutrition and mortality. All screening tools were applied under the supervision of two researchers from the Department of Nutrition and Dietetics.

\section{Subjective Global Assessment}

Subjective Global Assessment (SGA) is an assessment consisting of history of weight loss and dietary intake, gastrointestinal symptoms, functional capacity, metabolic requirement and physical examination. After scoring, patients were classified into three groups ( $A, B$ and C) as follows: well-fed: Group A, moderate malnutrition: Group B, severe malnutrition: Group C.

\section{Nutrition Risk Screening-2002}

Nutrition risk screening-2002 (NRS) was developed in 2002 by Kondrup et al. ${ }^{(11)}$. It is comprised of a 2-step screening process, the first 'initial screening' assesses the presence of the following: BMI value below 20.5 $\mathrm{kg} / \mathrm{m} 2$, weight loss within the last 3 months, reduction in dietary intake within the last week, and being hospitalized in an intensive care unit. If none of these conditions are met, the patient is considered 'low risk' for malnutrition; however, if any of these four conditions are met, then the 'final screening' step (comprised of 3 questions about nutritional status, disease severity and age). Nutritional status and disease severity are scored from 0 to 3 points, while age is scored with regard to being younger or older than 70 years ( 0 and 1 point, respectively). The risk of malnutrition according to the final score was assessed as follows: low risk: $0-3$ pts; at risk, 4 pts, and 'high risk 5-7 pts.

\section{Acute Physiology and Chronic Health Evaluation}

Acute Physiology and Chronic Health Evaluation (APACHE) II was developed by Knaus et al. ${ }^{(12)}$ in 1985 and is the most widely used scoring system for the 
evaluation of survival. It consists of three parts: acute physiology score, age and chronic health assessment. The range of the APACHE II score is from 0 to 71 points. As the total score increases, the estimated mortality rate also increases.

The APACHE III scoring system is a renewed and updated version of the APACHE II system ${ }^{(13)}$. Simply put, the diagnoses of primary disease section used in APACHE II are expanded and the clinic at which the patient is receiving care (intensive care, emergency room, ward etc.) is included in the assessment. The score range of the APACHE III is from 0 to 299 points, with higher scores indicating worse prognosis.

\section{Charlson Comorbidity Index}

Charlson Comorbidity Index (CCI) was developed by Charlson et al. ${ }^{(14)}$. In this scale, diseases that correlate with 1-year mortality are evaluated and scores are given according to patients' relative risks.

\section{Statistical Analysis}

The IBM SPSS Statistics software V21.0 (SPSS Inc., Chicago, IL) was used for all data analyses. Descriptive data were presented as numbers ( $n)$, percentages (\%), mean \pm standard deviation and median (range). The Kolmogorov-Smirnov test with Lilliefors correction was used to evaluate the normality of distribution of quantitative variables. Continuous variables were compared using the Students t-test or Mann-Whitney $U$ test, depending on normality of distribution. Categorical variables were compared using Pearson's chi-square test or Fisher's Exact test. Receiver operating characteristics (ROC) analysis was used to determine the effectiveness of screening tools (APACHE II, III, CCl and NRS) in predicting mortality. Logistic regression model was used to identify significant independent predictors of mortality. $P<0.05$ was accepted as the level of statistical significance.

\section{RESULTS}

The study group consisted of 249 patients (135 males, 114 females). The mean age of the study group was $61.3 \pm 16.5$ years. According to SGA, 150 (60.2\%) patients had moderate (SGA B), while 71 (28.5\%) patients had severe malnutrition (SGA C). The frequency of SGA C (severe malnutrition) in the immigrant group was significantly higher than Turkish citizens $(p=0.004)$. There were no significant differences

between Turkish citizens and immigrants in terms of age and BMI $(p>0.05)$. The duration of hospitalization was significantly longer in immigrants than in the Turkish citizens $(p<0.001)$.

Serum albumin levels were significantly lower in the immigrants compared to Turkish citizens $(p=0.014)$. APACHE II, APACHE III and CCl scores were significantly higher in the immigrant group compared to Turkish citzens ( $p<0.001$ for all). No significant difference was found between the groups in terms of NRS scores ( $p=0.653$ ). There was no significant difference between the Turkish citizens and immigrants in terms of intra-hospital 30-day and six-month mortality rates $(\mathrm{p}=0.571$ and $\mathrm{p}=0.069)$. Also, 30-day overall mortality rate was significantly higher in Turkish citizens $(p=0.045)$; however, six-month overall mortality rates were similar $(\mathrm{p}=0.080)$ (Table 1$)$.

Table 1. Comparison of Turkish nationals and immigrants.

\begin{tabular}{|c|c|c|c|}
\hline & Turkish nationals & Immigrants & $\mathbf{p}$ \\
\hline Age, mean $\pm S D$ & $64.0 \pm 14.6$ & $60.0 \pm 17.5$ & 0.052 \\
\hline BMI, mean \pm SD & $25.2 \pm 6.0$ & $24.5 \pm 7.1$ & 0.374 \\
\hline $\begin{array}{l}\text { Hospitalization (day), } \\
\text { mean } \pm S D\end{array}$ & $5.3 \pm 6.2$ & $11.4 \pm 18.4$ & 0.000 \\
\hline \multicolumn{4}{|l|}{ SGA, n (\%) } \\
\hline A & $15(14.6 \%)$ & $13(8.9 \%)$ & \\
\hline B & $70(68.0 \%)$ & $80(54.8 \%)$ & 0.004 \\
\hline C & $18(17.5 \%)$ & $53(36.3 \%)$ & \\
\hline Albumin, mean $\pm S D$ & $2.9 \pm 0.6$ & $2.7 \pm 0.6$ & 0.014 \\
\hline APACHE II, mean \pm SD & $12.7 \pm 8.6$ & $19.0 \pm 6.7$ & 0.000 \\
\hline APCAHE III, mean $\pm S D$ & $35.4 \pm 23.9$ & $55.4 \pm 34.9$ & 0.000 \\
\hline $\mathrm{CCl}$, mean $\pm \mathrm{SD}$ & $3.7 \pm 2.8$ & $5.2 \pm 2.5$ & 0.000 \\
\hline NRS, mean $\pm S D$ & $3.7 \pm 0.9$ & $3.6 \pm 0.7$ & 0.653 \\
\hline \multicolumn{4}{|l|}{ Last situation, $\mathrm{n}(\%)$} \\
\hline Alive & $67(65.0 \%)$ & $90(61.6 \%)$ & 0.592 \\
\hline Dead & $36(35.0 \%)$ & $56(38.4 \%)$ & \\
\hline \multicolumn{4}{|c|}{ 30-day intra-hospital mortality, n (\%) } \\
\hline$(-)$ & $98(95.1 \%)$ & $141(96.6 \%)$ & 0.571 \\
\hline$(+)$ & $5(4.9 \%)$ & $5(3.4 \%)$ & \\
\hline \multicolumn{4}{|c|}{ 6-month intra-hospital mortality, n (\%) } \\
\hline$(-)$ & $80(77.7 \%)$ & $98(67.1 \%)$ & 0.069 \\
\hline$(+)$ & $23(22.3 \%)$ & $48(32.9 \%)$ & \\
\hline \multicolumn{4}{|c|}{ 30-day all mortality, n (\%) } \\
\hline$(-)$ & $91(88.3 \%)$ & $139(95.2 \%)$ & 0.045 \\
\hline$(+)$ & $12(11.7 \%)$ & $7(4.8 \%)$ & \\
\hline \multicolumn{4}{|c|}{ 6-month all mortality, n (\%) } \\
\hline$(-)$ & $79(76.7 \%)$ & $97(66.4 \%)$ & 0.080 \\
\hline$(+)$ & $24(23.3 \%)$ & $49(33.6 \%)$ & \\
\hline
\end{tabular}

BMI: Body Mass Index

SGA: Subjective Global Assessment APACHE: Acute Physiology and Chronic Health Evaluation, 
Table 2. It showes comparison of preopertive and postoperative patients' VAS. A statistically significant decline in pain control was detected in both groups.

\begin{tabular}{|c|c|c|c|c|c|c|}
\hline & $\begin{array}{c}\text { Alive at } 6 \\
\text { months }\end{array}$ & $\begin{array}{c}\text { Died at } 1 \text { to } 6 \\
\text { months }\end{array}$ & p & Alive at $\mathbf{3 0}$ days & $\begin{array}{l}\text { Died within } 30 \\
\text { days }\end{array}$ & p \\
\hline Age, mean $\pm S D$ & $60.7 \pm 16.5$ & $65.6 \pm 16.4$ & 0.214 & $59,8 \pm 16,4$ & $64,1 \pm 16,3$ & 0,061 \\
\hline BMI, mean $\pm S D$ & $25.1 \pm 6.8$ & $21.2 \pm 3.6$ & 0.004 & $24,5 \pm 6,6$ & $25,5 \pm 6,7$ & 0,358 \\
\hline $\begin{array}{l}\text { Hospitalization } \\
(\text { day), mean } \pm \text { SD }\end{array}$ & $8,9 \pm 15,3$ & $8,6 \pm 11,0$ & 0,878 & $8,7 \pm 17,0$ & $9,4 \pm 8,3$ & 0,003 \\
\hline \multicolumn{7}{|l|}{ SGA, n (\%) } \\
\hline A & $28(12,2 \%)$ & $0(0 \%)$ & & $18(10,2 \%)$ & $10(13,7 \%)$ & \\
\hline B & $137(59,6 \%)$ & $13(68,4 \%)$ & 0,271 & $114(64,8 \%)$ & $36(49,3 \%)$ & 0,074 \\
\hline C & $65(28,3 \%)$ & $6(31,6 \%)$ & & $44(25,0 \%)$ & $27(37,0 \%)$ & \\
\hline \multicolumn{7}{|l|}{ Nationality, n (\%) } \\
\hline Turkish nationals & $79(44,9 \%)$ & $24(32,9 \%)$ & 0,080 & $91(39,6 \%)$ & $12(63,2 \%)$ & 0,045 \\
\hline Immigrant & $97(55,1 \%)$ & $49(67,1 \%)$ & & $139(60,4 \%)$ & $7(36,8 \%)$ & \\
\hline $\begin{array}{l}\text { Albumin, } \\
\text { mean } \pm S D\end{array}$ & $2,8 \pm 0,6$ & $2,6 \pm 0,5$ & 0,362 & $2,9 \pm 0,6$ & $2,5 \pm 0,5$ & 0,000 \\
\hline $\begin{array}{l}\text { APACHE II, } \\
\text { mean } \pm \text { SD }\end{array}$ & $15,1 \pm 8,6$ & $18,0 \pm 6,1$ & 0,067 & $13,3 \pm 7,1$ & $20,0 \pm 9,5$ & 0,000 \\
\hline $\begin{array}{l}\text { APCAHE III, } \\
\text { mean } \pm \text { SD }\end{array}$ & $46,3 \pm 31,6$ & $57,7 \pm 39,4$ & 0,175 & $36,8 \pm 24,9$ & $72,5 \pm 34,6$ & 0,000 \\
\hline $\mathrm{CCl}$, mean $\pm \mathrm{SD}$ & $4,2 \pm 2,7$ & $5,4 \pm 3,7$ & 0,232 & $4,0 \pm 2,6$ & $5,0 \pm 3,0$ & 0,017 \\
\hline NRS, mean $\pm S D$ & $3,6 \pm 0,8$ & $3,9 \pm 1,0$ & 0,233 & $3,6 \pm 0,8$ & $3,9 \pm 0,8$ & 0,007 \\
\hline
\end{tabular}

BMI: Body Mass Index

SGA: Subjective Global Assessment

APACHE: Acute Physiology and Chronic Health Evaluation,

The BMls of patients that died within 6 months were significantly lower than those who survived $(p=0.004)$. There was no significant difference between these groups in terms of other variables. Albumin values, APACHE II, APACHE III, CCl and NRS scores were significantly higher in those that died within 30 days (Table 2).

The APACHE 3 score was the most successful in predicting 30-day mortality according to ROC analysis (Table 3).

Table 3. Predicting 30-day mortality

\begin{tabular}{|l|c|c|c|}
\hline & $\begin{array}{c}\text { Area Under } \\
\text { the Curve }\end{array}$ & $\begin{array}{c}95 \% \text { Confidence } \\
\text { Interval }\end{array}$ & $\mathbf{p}$ \\
\hline APACHE 3 & 0,840 & $0,787-0,893$ & 0,000 \\
\hline APACHE 2 & 0,715 & $0,644-0,786$ & 0,000 \\
\hline CCI & 0,596 & $0,514-0,677$ & 0,020 \\
\hline NRS & 0,592 & $0,513-0,671$ & 0,026 \\
\hline
\end{tabular}

APACHE: Acute Physiology and Chronic Health Evaluation, CCl: Charlson Comorbidity Index, NRS: Nutrition risk screening
CCI: Charlson Comorbidity Index, NRS: Nutrition risk screening

Albumin and APACHE 3 scores were found to be successful in predicting 30-day mortality in the multivariate model (Table 4).

Table 4. Fracture levels of patients and the amount of collapse

\begin{tabular}{|l|c|c|c|c|c|c|}
\hline & \multicolumn{3}{|c|}{ Univariate Model } & \multicolumn{3}{c|}{ Multivariate Model } \\
\cline { 2 - 7 } & OR & $\begin{array}{c}95 \% \\
\text { Confidence } \\
\text { Interval }\end{array}$ & $p$ & OR & $\begin{array}{c}95 \% \\
\text { Confidence } \\
\text { Interval }\end{array}$ & $p$ \\
\hline $\begin{array}{l}\text { Albu- } \\
\text { min }\end{array}$ & 0,272 & $0,158-0,468$ & 0,000 & 0,457 & $0,242-0,864$ & 0,016 \\
\hline $\begin{array}{l}\text { APACHE } \\
\text { II }\end{array}$ & 1,125 & $1,076-1,176$ & 0,000 & & & \\
\hline $\begin{array}{l}\text { APCAHE } \\
\text { III }\end{array}$ & 1,038 & $1,027-1,050$ & 0,000 & 1,037 & $1,025-1,049$ & 0,000 \\
\hline CCI & 1,134 & $1,026-1,253$ & 0,013 & & & \\
\hline NRS & 1,563 & $1,115-2,191$ & 0,010 & & & \\
\hline $\begin{array}{l}\text { Hospi- } \\
\text { taliza- } \\
\text { tion }\end{array}$ & 1,003 & $0,986-1,021$ & 0,733 & & & \\
\hline
\end{tabular}

OR: Odds ratio

APACHE: Acute Physiology and Chronic Health Evaluation,

CCI: Charlson Comorbidity Index,

NRS: Nutrition risk screening 


\section{DISCUSSION}

In the present study, malnutrition among immigrants and Turkish citizens was evaluated and patients hospitalized in the ICU due to colorectal or non-colorectal gastrointestinal cancers were compared in terms of mortality. Overall, we found malnutrition in $221(88.7 \%)$ patients. Of the patients with malnutrition, $88(39.8 \%)$ were Turkish citizens and 133 (60.2\%) were immigrants. In our study, malnutrition was more common in immigrants. The frequency of SGA C (severe malnutrition) was significantly higher in the immigrant group compared to the patients with Turkish nationality. Even though, our results demonstrated that malnutrition rates were unexpectedly high in both immigrants and Turkish citizens, this condition may be associated with the fact that many of these patients had been suffering from gastrointestinal cancers and were receiving different types of treatment. Despite the possibility that disease stage, treatment types and patient characteristics could have contributed to the presence and severity of malnutrition, these data identify malnutrition as a high priority target, especially in hospitalized patients. Similarly, in a study where indigenous and non-indigenous people were compared in terms of malnutrition, the overall frequency of malnutrition was reported to be $41.1 \%$, and malnutrition was more common in the non-Indigenous group ${ }^{(15)}$.

The duration of hospitalization was significantly higher in immigrants than in the Turkish citizens $(p<0.001)$. Considering that immigrants were in significantly worse state in terms of malnutrition, it is apparent that this finding is in agreement with a study that reported nutritional status as an independent variable for the length of hospital stay ${ }^{(16)}$. Therefore, we believe that the presence of malnutrition was the cause of prolonged hospital stay among immigrants in the current study.

The overall mortality rate in our study was 36.9 percent. No significant difference was found between Turkish citizens and immigrants in terms of overall mortality. We determined that the APACHE III score and albumin value were successful in predicting mortality. However, it was concluded that the APACHE 3 score was the most successful predictor of mortality. In a study assessing the health-related needs of Syrian refugees conducted in Turkey, it was concluded that malnutrition has become a major health problem in Turkey because malnutrition had an impact on mortality either directly or indirectly ${ }^{(17)}$. In an another study by Lim et al. ${ }^{(18)}$, it was reported that malnutrition negatively affected the length of hospital stay, re-admission rates and mortality. Thus, we believe that determining the presence or risk of malnutrition at admission is crucial to predict prognosis of the patient and to prevent associated negative health consequences.

The relatively short follow-up duration (six months) is one of the limitations of the current study, since mortality rates, especially those associated with nutrition, may be only evident at longer term follow-up. Another limitation is the fact that treatments for malnutrition and their results were not assessed in this study; therefore, patients that received direct treatment in this regard may have skewed our results. However, the aim of this study was to assess differences between immigrants and Turkish citizens with regard to malnutrition. Nevertheless, future studies should take into account this characteristic of patients. Finally, we also had no data regarding patient admission to other hospitals during follow-up, which may have affected mortality findings.

\section{Conclusion}

This study revealed the presence of high malnutrition and mortality rates in immigrants and Turkish citizens that were hospitalized in the ICU due to gastrointestinal cancers. However, it was found that especially severe malnutrition was more frequent in the immigrant group. In addition, this study showed that the APACHE III score was the most successful tool in predicting mortality. In order to prevent negative health consequences of malnutrition, patients should be evaluated in terms of malnutrition and protected from malnutrition, both during hospitalization and after discharge.

Ethics Committee Approval: The study was approved by Ethics Committee of Non-Interventional Clinical Researches of Adana Metropolitan City Research and Training Hospital (Decision No.355 and Decision Date 19.12.2018).

Conflict of Interest: No conflict of interest was declared by the authors.

Funding: No funding was used for this study.

Informed Consent: Informed consent was obtained from all individual participants included in the study. 


\section{REFERENCES}

1. NutritionWorks, Emergency Nutrition Network Cluster, Global Nutrition. The Harmonised Training Package (HTP): Resource Material for Training on Nutrition in Emergencies. 2011.

2. El-Khatib Z, Scales D, Vearey J, Forsberg BC. Syrian refugees, between rocky crisis in Syria and hard inaccessibility to healthcare services in Lebanon and Jordan. Confl Health. 2013;7(1):18. https://doi.org/10.1186/1752-1505-7-18

3. Dawson-Hahn EE, Pak-Gorstein S, Hoopes AJ, Matheson J. Comparison of the nutritional status of overseas refugee children with low income children in Washington State. PLoS One. 2016;11(1):e0147854.

https://doi.org/10.1371/journal.pone.0147854

4. Boulos C, Adib SM, Mitri R, Salameh P. Nutritional Status of the Elderly in an Arab Country in Social Transition: The Case of Lebanon. In: Preedy VR, Patel VB, editors. Handbook of Famine, Starvation, and Nutrient Deprivation. Springer International Publishing; 2017.

https://doi.org/10.1007/978-3-319-40007-5_33-1

5. Fávaro-Moreira NC, Krausch-Hofmann S, Matthys C, Vereecken C, Vanhauwaert E, Declercq A, et al. Risk factors for malnutrition in older adults: a systematic review of the literature based on longitudinal data. Adv Nutr. 2016;7(3):507-22. https://doi.org/10.3945/an.115.011254

6. Ahmed T, Haboubi N. Assessment and management of nutrition in older people and its importance to health. Clin Interv Aging. 2010;5:207-16.

\section{https://doi.org/10.2147/CIA.S9664}

7. Bahwere P. Severe acute malnutrition during emergencies: burden, management, and gaps. Food Nutr Bull. 2014;35(2 Suppl):S47-51.

https://doi.org/10.1177/15648265140352\$107

8. Gezahegn Y, Kassahun W, Dube L. Factors associated with acute malnutrition among south Sudanese children in Tierkidi refugee camp: a case-control study. Qual Prim Care. 2017;25(4):253-8. Available from: https://www.researchgate.net/profile/ Yenealem_Gezahegn/publication/334599029

9. Pernitez-Agan S, Wickramage K, Yen C, Dawson-Hahn E, Mitchell T, Zenner D. Nutritional profile of Syrian refugee children before resettlement. Confl Health. 2019;13:22. https://doi.org/10.1186/s13031-019-0208-y
10. Hossain SM, Leidman E, Kingori J, Al Harun A, Bilukha OO. Nutritional situation among Syrian refugees hosted in Iraq, Jordan, and Lebanon: cross sectional surveys. Confl Health. 2016;10:26. https://doi.org/10.1186/s13031-016-0093-6

11. Kondrup J, Rasmussen HH, Hamberg O, STANGA Z, Group AAHEW. Nutritional risk screening (NRS 2002): A new method based on an analysis of controlled clinical trials. Clin Nutr. 2003;22(3):321-36. https://doi.org/10.1016/S0261-5614(02)00214-5

12. Knaus WA, Draper EA, Wagner DP, Zimmerman JE. APACHE II: A severity of disease classification system. Crit Care Med. 1985;13(10):818-29. PMID: 3928249. https://doi.org/10.1097/00003246-198510000-00009

13. Knaus WA, Wagner DP, Draper EA, Zimmerman JE, Bergner M, Bastos PG, et al. The APACHE III prognostic system: risk prediction of hospital mortality for critically III hospitalized adults. Chest. 1991;100(6):1619-36. https://doi.org/10.1378/chest.100.6.1619

14. Charlson ME, Pompei $P$, Ales KL, MacKenzie CR. A new method of classifying prognostic comorbidity in longitudinal studies: development and validation. J Chronic Dis. 1987;40(5):373-83. https://doi.org/10.1016/0021-9681(87)90171-8

15. Morris N, Stewart S, Riley M, Maguire G. Differential Impact of Malnutrition on Health Outcomes Among Indigenous and NonIndigenous Adults Admitted to Hospital in Regional Australia - A Prospective Cohort Study. Nutrients. 2018;10(5):644. https://doi.org/10.3390/nu10050644

16. Abrha MW, Seid O, Gebremariam K, Kahsay A, Weldearegay HG. Nutritional status significantly affects hospital length of stay among surgical patients in public hospitals of Northern Ethiopia: single cohort study. BMC Res Notes. 2019;12(1):416. https://doi.org/10.1186/s13104-019-4451-5

17. Assi R, Özger-illhan S, İlhan M. Health needs and access to health care: The case of Syrian refugees in Turkey. Public Health. 2019;172:146-52. https://doi.org/10.1016/j.puhe.2019.05.004

18. Lim SL, Ong KCB, Chan YH, Loke WC, Ferguson M, Daniels L. Malnutrition and its impact on cost of hospitalization, length of stay, readmission and 3-year mortality. Clin Nutr. 2012;31(3):34550. https://doi.org/10.1016/j.clnu.2011.11.001 